\title{
Wabash River Integrated Methanol and Power Production from Clean Coal Technologies (IMPPCCT)
}

Quarterly Technical Progress Report No. 16

\author{
For the Period \\ July 1 - September 30, 2003 \\ Report Date: January 7, 2004 \\ Prepared For \\ U.S. Department of Energy \\ Cooperative Agreement No. DE-FC26-99FT40659 \\ by \\ ConocoPhillips Company \\ 600 N. Dairy Ashford \\ Houston, Texas 77079-1175
}




\section{DISCLAIMER}

This report was prepared by ConocoPhillips Company as an account of work pursuant to a cooperative agreement partially sponsored by an agency of the United Sates Department of Energy. Neither the ConocoPhillips Company, nor any of its subcontractors, nor the United States Department of Energy, nor any person or agency acting on behalf of either:

(A) Makes any warranty, express or implied, or assumes any legal liability or responsibility for the accuracy. Completeness, or usefulness of any information, apparatus, product or process disclosed, or represents that its use would not infringe privately owned rights.

(B) Assumes any liabilities with respect to the use of, or for damages resulting from the use of any information, apparatus, method or process disclosed in this report.

Reference herein to any specific commercial product, process, or service by trade name, trademark, manufacturer, or otherwise does not necessarily constitute or imply its endorsement, recommendation, or favoring by the United States Department of Energy nor any agency thereof. The views and opinions of authors expressed therein do not necessarily state or reflect those of the United States Department of Energy or any agency thereof. 


\begin{abstract}
The Wabash River Integrated Methanol and Power Production from Clean Coal Technologies (IMPPCCT) project is evaluating integrated electrical power generation and methanol production through clean coal technologies. The project is conducted by a multi-industry team lead previously by Gasification Engineering Corporation (GEC). The project is now under the leadership of ConocoPhillips Company (COP) after it acquired GEC and the E-Gas ${ }^{\mathrm{TM}}$ gasification technology from Global Energy in July 2003. The Phase I of this project was supported by Air Products and Chemicals, Inc., Dow Chemical Company, Dow Corning Corporation, Methanex Corporation, and Siemens Westinghouse Power Corporation, while the Phase II is supported by Gas Technology Institute, TDA Research, Inc., and Nucon International, Inc. The two project phases planned for execution include:
\end{abstract}

I. Feasibility study and conceptual design for an integrated demonstration facility at Global Energy's existing Wabash River Energy Limited (WREL) plant in West Terre Haute, Indiana, and for a fence-line commercial embodiment plants (CEP) operated at Dow Chemical or Dow Corning chemical plant locations

II. Research, development, and testing (RD\&T) to define any technology gaps or critical design and integration issues.

The WREL facility was designed, constructed, and operated under a project selected and co-funded under the Round IV of the United States Department of Energy's (DOE's) Clean Coal Technology Program. In this project, coal and/or other solid fuel feedstocks are gasified in an oxygen-blown, entrained-flow gasifier with continuous slag removal and a dry particulate removal system. The resulting product synthesis gas is used to fuel a combustion turbine generator whose exhaust is integrated with a heat recovery steam generator to drive a refurbished steam turbine generator. The gasifier uses technology initially developed by The Dow Chemical Company (the Destec Gasification Process), and now acquired and offered commercially by COP as the E-GAS ${ }^{\mathrm{TM}}$ technology. 
In a joint effort with the DOE, a Cooperative Agreement was awarded under the Early Entrance Coproduction Plant (EECP) solicitation. GEC, and now COP and the industrial partners are investigating the use of synthesis gas produced by the E-GAS ${ }^{\mathrm{TM}}$ technology in a coproduction environment to enhance the efficiency and productivity of solid fuel gasification combined cycle power plants.

The objectives of this effort are to determine the feasibility of an EECP located at a specific site which produces some combination of electric power (or heat), fuels, and/or chemicals from synthesis gas derived from coal, or, coal in combination with some other carbonaceous feedstock. The project's intended result is to provide the necessary technical, economic, and environmental information that will be needed to move the EECP forward to detailed design, construction, and operation by industry.

During the reporting period, agreement was reached with DOE's patent counsel on the scope of the limited rights data to be provided under the Phase II of the Cooperative Agreement. Notice for approval of the Continuation Application of the project into Phase II to conduct RD\&T was received from DOE in September 2003. Funding from Phase I will be used to fund the RD\&T activities in Phase II. The project schedule was adjusted to reflect the delay in starting Phase II, originally planned for April 2003. Potential technologies for removing sulfur contaminants from synthesis gas to the level required by methanol synthesis will be tested in slipstream units at the WREL facility during Phase II.

Preparation of a comprehensive Phase I Final Report, which will consolidate the remaining deliverables including the Initial Feasibility Report, Concept Report, Site Analysis Report, Economic Analysis, and Preliminary Project Financing Plan, continued during the reporting period. Progress was hindered by the change in ownership of GEC. The IMPPCCT Project, along with other DOE-funded projects previously managed by GEC, is being novated to COP, the new owner of the E-Gas ${ }^{\mathrm{TM}}$ gasification technology. 


\section{TABLE OF CONTENTS}

DISCLAIMER

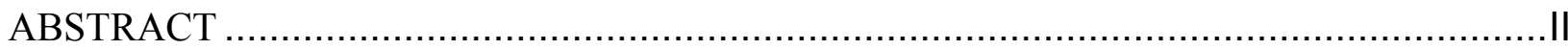

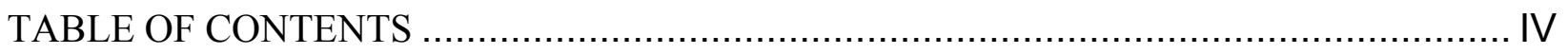

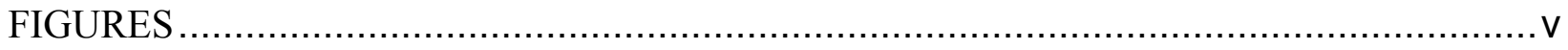

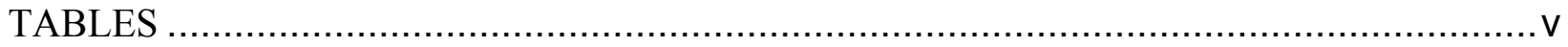

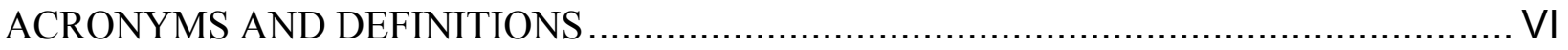

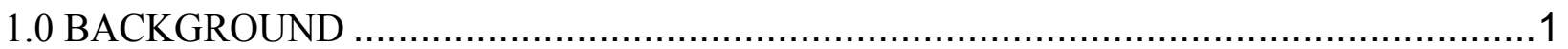

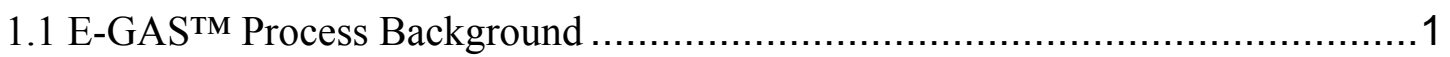

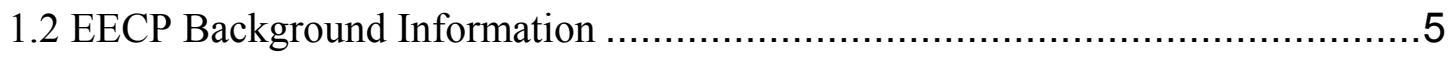

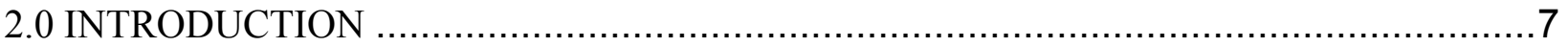

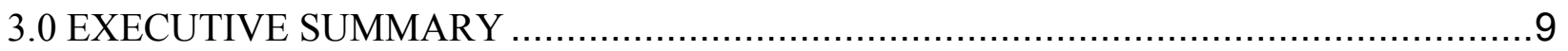

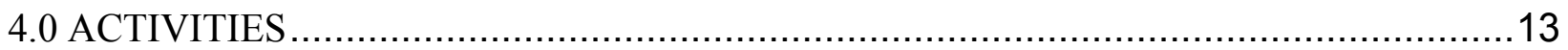

4.1 Finalizing the Continuation Application ..................................................13

4.2 Planning for Phase II RD\&T …......................................................13

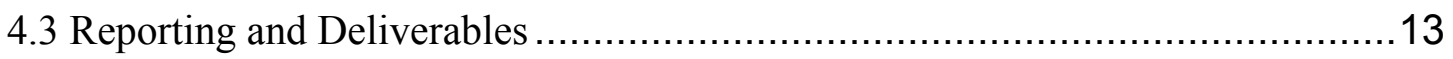

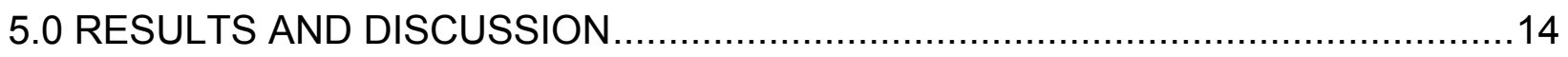

5.1 Finalizing the Continuation Application ................................................14

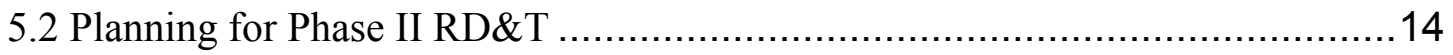

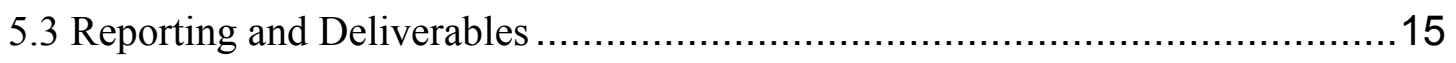

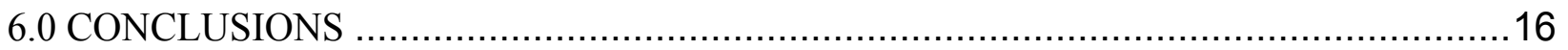

6.1 Finalizing the Continuation Application ...............................................16

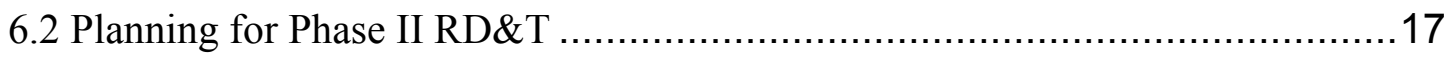

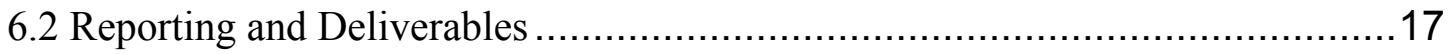

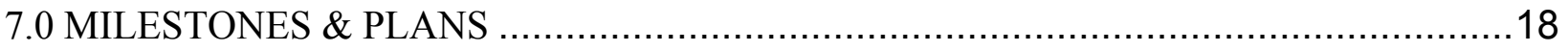

7.1 Plans for Commencing on Phase II and Completing Phase I ..........................18

7.2 Project Schedule and Milestones ..............................................................18 
7.3 Project Spending -- Plan and Actuals

\section{FIGURES}

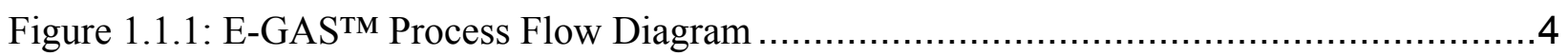

Figure 7.2.1 : Phase I, IMPPCCT Milestones (rev.).....................................................20

Figure 7.3.1: Phase I Project Spending -- Overall ....................................................21

Figure 7.3.2: Phase I Project Spending -- DOE Funding............................................................22

\section{TABLES}

Table 1.1.1 - WREL Gasification Production Statistics during the Demonstration Period of the Clean Coal Technology Program...........................................................................4

Table 1.1.2: Overall Thermal Performance of Gasification at WREL ………...............................5 
ACRONYMS AND DEFINITIONS

\begin{tabular}{|c|c|}
\hline Acronym & Description \\
\hline ASU & Air Separation Unit \\
\hline BFW & Boiler Feed-Water \\
\hline $\mathrm{CC}$ & Combined Cycle (plant including only HRSG, CT \& ST) \\
\hline CEP & Commercial Embodiment Plant \\
\hline CT & Combustion Turbine \\
\hline $\mathrm{CCT}$ & Clean Coal Technologies \\
\hline $\mathrm{COP}$ & ConocoPhillips Company \\
\hline DOE & Department of Energy \\
\hline EECP & Early Entrance Coproduction Plant \\
\hline E-GAS ${ }^{\text {TM }}$ & Title of Global Energy, Inc.'s Gasification Process \\
\hline GEC & Gasification Engineering Corporation \\
\hline HHV & Higher Heating Value in Btu/SCF \\
\hline HRSG & Heat Recovery Steam Generator \\
\hline HTHRU & High Temperature Heat Recovery Unit \\
\hline IGCC & Integrated Gasification Combined Cycle \\
\hline IMPPCCT & $\begin{array}{l}\text { Integrated Methanol and Power Production from Clean Coal } \\
\text { Technologies }\end{array}$ \\
\hline LGTI & Louisiana Gasification Technology Incorporated \\
\hline LOX & Liquid Oxygen \\
\hline LPMEOH $^{\mathrm{TM}}$ & Liquid Phase Methanol (process) \\
\hline MAC & Main Air Compressor \\
\hline MDEA & Methyl-Di-Ethanol Amine (solvent) \\
\hline $\mathrm{MeOH}$ & Methanol \\
\hline MMBtu & Million British Thermal Units \\
\hline Mt & Metric Ton \\
\hline MTPD & Metric Ton Per Day \\
\hline
\end{tabular}




\begin{tabular}{|c|c|}
\hline Acronym & Description \\
\hline MW & Mega Watt \\
\hline NETL & National Energy Technology Laboratory \\
\hline NOx & Oxides of Nitrogen (symbol) \\
\hline NPV & Net Present Value \\
\hline O\&M & Operating \& Maintenance \\
\hline PPMV & Parts Per Million Volume \\
\hline PSE & Power Systems Engineering \\
\hline RD\&T & Research, Development \& Test (plan) \\
\hline SCF & Standard Cubic Foot \\
\hline SFC & Synthetic Fuels Corporation \\
\hline ST & Steam Turbine \\
\hline Syngas & Synthesis Gas \\
\hline TPD & Tons Per Day \\
\hline WBS & Work Breakdown Structure (activities) \\
\hline WREL & Wabash River Energy Ltd. \\
\hline
\end{tabular}




\subsection{BACKGROUND}

\subsection{E-GASTM Process Background}

The E-GAS ${ }^{\text {TM }}$ gasification technology, recently acquired by ConocoPhillips Company (COP), is utilized at the Wabash River Energy Ltd., (WREL) facility located at Cinergy's Wabash River Generating Station in West Terre Haute, Indiana. WREL is a subsidiary of Global Energy, Inc., the previous owner of the E-GAS ${ }^{\text {TM }}$ technology. COP, headquartered in Houston Texas, continues to develop and market the technology.

The E-GAS ${ }^{\text {TM }}$ process features an oxygen-blown, continuous-slagging, two-stage, entrainedflow gasifier, which uses natural gas for start-up. Coal or petroleum coke is milled with water in a rod-mill to form slurry. The slurry is combined with oxygen in mixer nozzles and injected into the first stage of the gasifier, which operates at approximately $2600^{\circ} \mathrm{F}$ and $400 \mathrm{psi}$. A turnkey, Air Liquide, 2,060-ton/day low-pressure cryogenic distillation facility that WREL owns and operates, supplies oxygen of $95 \%$ purity.

In the first stage, slurry fuel undergoes a partial oxidation reaction at temperatures high enough to bring the coal's ash above its melting point. The fluid ash falls through a taphole at the bottom of the first stage into a water quench, forming an inert vitreous slag. The synthesis gas produced by this reaction then flows to the second stage, where additional coal slurry is injected. This coal is pyrolyzed in an endothermic reaction with the hot synthesis gas to enhance the heating value of the synthesis gas and to improve the overall efficiency of the process.

The synthesis gas then flows to the high-temperature heat-recovery unit (HTHRU), essentially a fire tube steam generator, to produce high-pressure saturated steam. After cooling in the HTHRU, particulates in the synthesis gas called char are removed in a hot/dry filter and recycled to the gasifier where the carbon content in the char is converted into synthesis gas. The synthesis gas is further cooled in a series of heat exchangers, is water scrubbed to remove the chloride, and is passed through a catalyst, which hydrolyzes carbonyl sulfide into hydrogen sulfide. Hydrogen sulfide is removed from the synthesis gas using a methyl-di-ethanol-based amine solvent in an 
absorber/stripper column process. The "sweet" synthesis gas is then moisturized, preheated, and piped over to the power block.

The key elements of the power block are the General Electric MS 7001 FA (GE 7 FA) hightemperature combustion turbine/generator, the heat recovery steam generator (HRSG), and the repowered steam turbine. The GE 7 FA is a dual-fuel turbine (synthesis gas for operations and No. 2 fuel oil for startup) that is capable of generating a nominal $192 \mathrm{MW}$ when firing synthesis gas, about seven percent (7\%) higher power production than the same turbine fired on natural gas. The enhanced power production is attributed to the increased mass flows associated with synthesis gas. Steam injection is used for control of nitrogen oxides called NOx within the combustion turbine. The required steam flow is minimal compared to that of conventional systems as the synthesis gas is moisturized at the gasification facility, by recovery of low-level heat in the process. The water consumed in this process is continuously made up at the power block by water treatment systems, which clarify and further treat river water.

The HRSG for this project is a single-drum design capable of superheating $754,000 \mathrm{lb} / \mathrm{hr}$ of high-pressure steam at $1010^{\circ} \mathrm{F}$, and $600,820 \mathrm{lb} / \mathrm{hr}$ of reheat steam at $1010^{\circ} \mathrm{F}$ when operating on design-basis synthesis gas. The HRSG configuration was specifically optimized to utilize both the gas-turbine exhaust energy and the heat energy made available in the gasification process. The nature of the gasification process in combination with the need for strict temperature and pressure control of the steam turbine led to a great deal of creative integration between the HRSG and the gasification facility. The repowered steam turbine produces $104 \mathrm{MW}$, which combines with the combustion turbine generator's $192 \mathrm{MW}$ and the system's auxiliary load of approximately $34 \mathrm{MW}$ to yield $262 \mathrm{MW}$ (net) to the Cinergy grid.

The Air Separation Unit (ASU) provides oxygen and nitrogen for use in the gasification process but is not an integral part of the plant thermal balance. The ASU uses services such as cooling water and steam from the gasification facilities and is operated from the gasification plant control room. 
The gasification facility produces two commercial by-products during operation. Sulfur, which is ultimately removed as 99.99 percent pure elemental sulfur, is marketed to sulfur users. Slag is targeted as an aggregate in asphalt roads and as structural fill in various types of construction applications. In fact, the roads at the WREL facility have been top-coated with asphalt incorporating slag as the aggregate. Furthermore, at least two surrounding area sites have been audited, approved, and have used WREL-generated slag as structural fill under the Solid Waste Management Rules of Indiana. Another beneficial use of the slag by-product is as a fluxing agent during petroleum coke operation as this feed is typically deficient in mineral content required for proper slag fusion and flow. For this use, WREL has retained a reserve supply of slag generated from coal gasification.

The E-GAS ${ }^{\mathrm{TM}}$ process flow diagram presented in Figure 1.1.1 illustrates the features and components described in the above text. In Table 1.1.1, the WREL production statistics during the demonstration period of the Clean Coal Technology Program are presented in both English and Metric units. In Table 1.1.2, the WREL thermal performance variables are compared to the process design basis for both coal and petroleum coke feedstocks.

Please refer to the listing in Section 8.1 of this report for additional information on the Wabash River Coal Gasification Plant. 
Figure 1.1.1: E-GASTM Process Flow Diagram

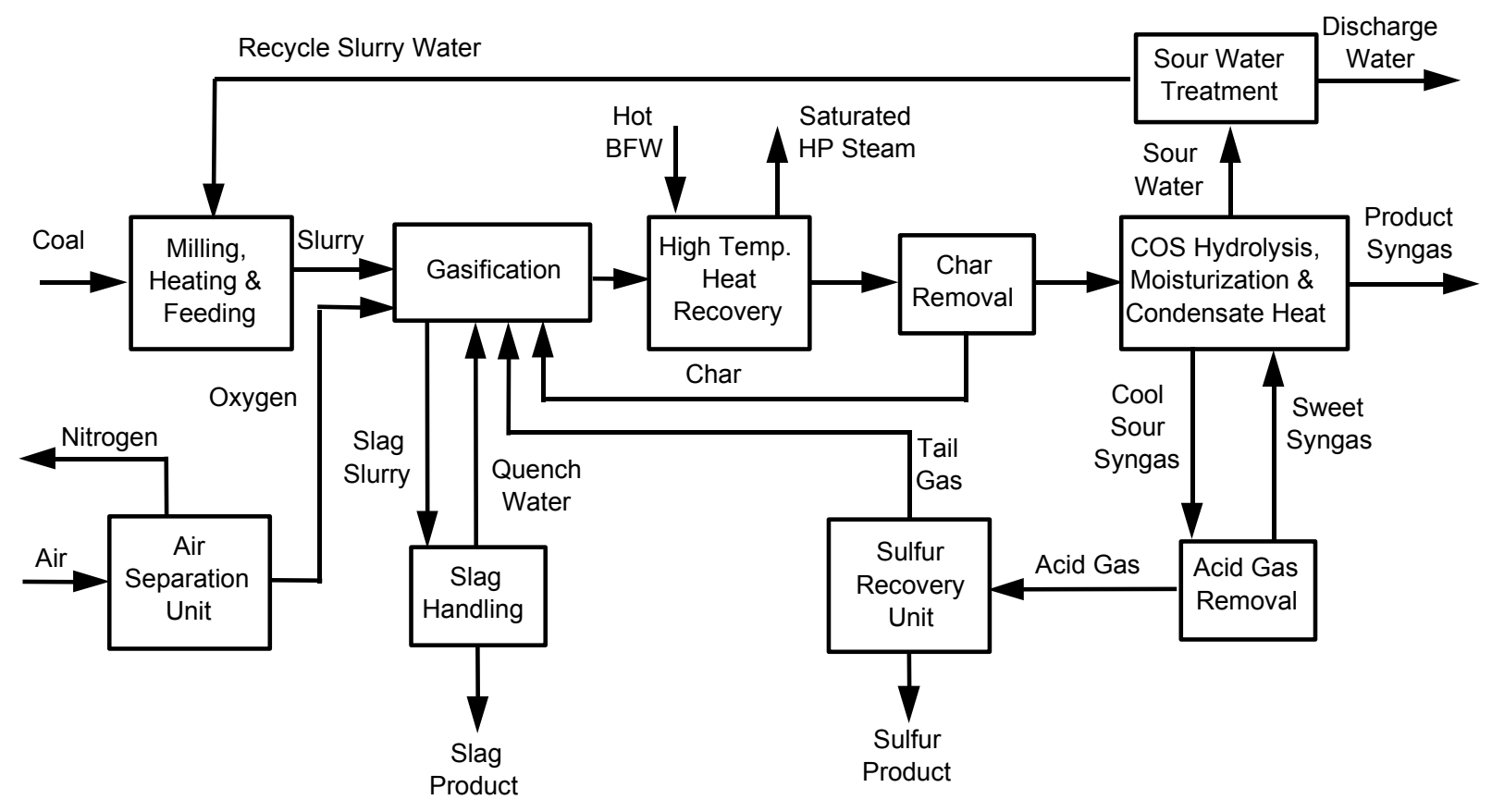

Table 1.1.1 - WREL Gasification Production Statistics during the Demonstration Period of the Clean Coal Technology Program

\begin{tabular}{|c|c|c|c|c|c|}
\hline \multirow{2}{*}{ Production Variable } & \multicolumn{5}{|c|}{ Production Year } \\
\cline { 2 - 6 } & 1996 & 1997 & 1998 & 1999 & 2000 \\
\hline Gasifier Operation, Hrs & 1,902 & 3,885 & 5,279 & $3,496^{*}$ & $3,406^{* *}$ \\
\hline $\begin{array}{c}\text { Dry Synthesis Gas } \\
\text { Produced, GJ (MMBtu) }\end{array}$ & $\begin{array}{c}2,922,015 \\
(2,769,683)\end{array}$ & $\begin{array}{c}6,555,626 \\
(6,213,864)\end{array}$ & $\begin{array}{c}9,316,716 \\
(8,831,011)\end{array}$ & $\begin{array}{c}6,132,874 \\
(5,813,151)\end{array}$ & $\begin{array}{c}5,497,588 \\
(5,210,984)\end{array}$ \\
\hline $\begin{array}{c}\text { Coal Processed, Mt } \\
\text { (Tons) }\end{array}$ & $\begin{array}{c}167,270 \\
(184,381)\end{array}$ & $\begin{array}{c}356,368 \\
(392,822)\end{array}$ & $\begin{array}{c}500,316 \\
(551,495)\end{array}$ & $\begin{array}{c}335,538 \\
(369,862)\end{array}$ & $\begin{array}{c}290,034 \\
(319,703)\end{array}$ \\
\hline $\begin{array}{c}\text { Longest Operating } \\
\text { Campaign, (days) }\end{array}$ & 19 & 46 & 82 & 60 & 104 \\
\hline
\end{tabular}

* Three months of production were lost to the GE 7FA compressor failure \& repair.

** Three months of production were lost during commercial negotiations required when the WREL Facility transitioned to market-based operation. 
Table 1.1.2: Overall Thermal Performance of Gasification at WREL

\begin{tabular}{|l|c|c|c|}
\hline \multicolumn{1}{|c|}{ Performance Feature } & \multirow{2}{*}{ Design } & \multicolumn{2}{|c|}{ Actual Performance } \\
\cline { 3 - 4 } & & Coal & Coke \\
\hline NOMINAL THROUGHPUT, TPD & 2550 & 2450 & 2000 \\
\hline Synthesis gas Capacity, MMBtu/hr & & $1690^{\dagger}$ & $1690^{\dagger}$ \\
\hline Combustion Turbine, MW & 1780 & 192 & 192 \\
\hline Steam Turbine, MW & 192 & 96 & 96 \\
\hline Aux. Power, MW & 105 & 36 & 36 \\
\hline Net Generation, MW & 35 & 261 & 261 \\
\hline Plant Efficiency, \% (HHV) & 262 & 39.7 & 40.2 \\
\hline Sulfur Removal Efficiency, \% & 37.8 & $>99$ & $>99$ \\
\hline
\end{tabular}

${ }^{\top}$ Synthesis gas capacity referenced for coal and petroleum coke are the actual quantities fed to the combustion turbine when 192 MW (100\%) of power generation occurs.

\subsection{EECP Background Information}

The request for Cooperative Agreement Proposals under the "Early Entrance Coproduction Plant (EECP)," Solicitation Number DE-SC26-99FT40040 was issued on February 17, 1999, by the United States Department of Energy.

The objective of this effort is to determine the feasibility of an EECP located at a specific site which produces some combination of electric power (or heat), fuels, and/or chemicals from synthesis gas derived from coal, or, coal in combination with some other carbonaceous feedstock. The scope of this effort includes:

a. Market analysis to define site-specific product requirements (i.e. products needed by market, market size, and price), process financials, feedstock availability, and feedstock cost; 
b. System analysis to define feedstocks, feedstock preparation, conversion to synthesis gas, synthesis gas cleanup, and conversion of synthesis gas to marketidentified products;

c. Preliminary engineering design of the EECP facility;

d. Preparation of a research, development, and testing (RD\&T) Plan that addresses the technical uncertainties associated with eventual design, construction, and operation of the EECP;

e. Implementation of RD\&T Plan;

f. Update of the preliminary engineering design; and

g. Update of the preliminary economic analysis.

Efforts under Solicitation No. DE-SC26-99FT40040 must support an EECP that at a minimum:

1. Is a single-train facility of sufficient size to permit scaling to commercial size with minimal technical risk;

2. Provides the capability of processing multiple feedstocks (must be capable of processing coal) and producing more than one product;

3. Is undertaken by an industrial consortium;

4. Reduces risk such that future coproduction plants may be deployed with no government assistance; and

5. Meets or exceeds environmental requirements and discusses the issue of carbon dioxide reduction by one or more routes, which include mitigation, utilization, and sequestration.

Using a focused RD\&T Plan, the EECP Project will enhance the development and commercial acceptance of coproduction technology that produces high-value products, particularly those that are critical to our domestic chemical, fuel, and power requirements. The project will resolve critical knowledge and technology gaps on the integration of gasification and downstream processing to coproduce some combination of power, fuels and/or chemicals from coal or coal in combination with other carbonaceous feedstocks. The project's intended result is to provide the necessary technical, financial, and environmental information that will be needed to move the EECP forward to detailed design, construction, and operation by industry. 


\subsection{INTRODUCTION}

The Wabash River Integrated Methanol and Power Production from Clean Coal Technologies (IMPPCCT) Project is a $\$ 4.92$ million cooperative agreement awarded by the United States Department of Energy (DOE) to the former Gasification Engineering Corporation (GEC) owned by Global Energy and now acquired by ConocoPhillips (COP), to evaluate the integration of gasification-based electrical generation and methanol production processes to determine the economic and technical feasibility of power and chemicals coproduction. A multi-industry team led by the previous GEC and consisting of Air Products \& Chemicals, Inc., Dow Chemical Company, Dow Corning Corporation, Methanex Corporation, and Siemens Westinghouse Power Corporation performed and completed the Phase I IMPPCCT study. The Phase II, which has just commenced, is led by COP and is supported by Gas Technology Institute, TDA Research, Inc., and Nucon International, Inc.

The Wabash River IMPPCCT team plans to analyze and develop a concept of methanol and power production based on the E-GAS ${ }^{\mathrm{TM}}$ gasification technology, now owned and licensed by COP, utilizing coal and other feedstocks. In a planned two-phase project, this team plans to review and analyze the domestic methanol market, examine the criteria needed and develop a robust financial model to study the economics of full-scale implementation of this gasification to power and methanol coproduction concept. Potential Dow Chemical and Dow Corning sites for the Commercial Embodiment Plant (CEP) will be examined. Feasibility studies, testing and engineering, and economics of IMPPCCT based on addition of methanol production facilities at the Wabash River Energy Limited (WREL) Gasification Plant in West Terre Haute, Indiana will be developed to enable the commercialization of the gasification to power and methanol coproduction concept.

The vision of this project is to demonstrate the commercial viability of producing electric power, process energy (steam), and chemicals (methanol) from coal and other hydrocarbon feedstocks to satisfy the demands of at least two types and corresponding sizes of host chemical complexes. An efficient, low capital, integrated facility will convert the feedstock initially to synthesis gas and ultimately to electric power, process energy, and methanol with a series of reliable, 
commercially-proven, and environmentally-sound unit operations. The chemical products, required process energy, and at least a portion of the electric power will be delivered to the host chemical complex for further conversion to higher value products. Any products in excess of the requirements of the host chemical complex will be sold through readily accessible distribution networks. The CEP will be technically verified from the implementation of the RD\&T Plan and commercially verified by an economic model. 


\subsection{EXECUTIVE SUMMARY}

The Wabash River Integrated Methanol and Power Production from Clean Coal Technologies (IMPPCCT) project is evaluating integrated electrical power generation and methanol production through clean coal technologies. The project is conducted by a multi-industry team lead previously by Gasification Engineering Corporation (GEC). The project is now under the leadership of ConocoPhillips Company (COP) after it acquired GEC and the E-Gas ${ }^{\mathrm{TM}}$ gasification technology from Global Energy in July 2003. The Phase I of this project was supported by Air Products and Chemicals, Inc., Dow Chemical Company, Dow Corning Corporation, Methanex Corporation, and Siemens Westinghouse Power Corporation, while the Phase II is supported by Gas Technology Institute, TDA Research, Inc., and Nucon International, Inc. The two project phases planned for execution include:

III. Feasibility study and conceptual design for an integrated demonstration facility at Global Energy's existing Wabash River Energy Limited (WREL) plant in West Terre Haute, Indiana, and for a fence-line commercial embodiment plants (CEP) operated at Dow Chemical or Dow Corning chemical plant locations

IV. Research, development, and testing (RD\&T) to define any technology gaps or critical design and integration issues.

The Wabash River Repowering Project, a joint effort between Wabash River Energy Limited (WREL) and Cinergy, was selected and co-funded under Round IV of the United States Department of Energy's (DOE's) Clean Coal Technology Program. In this project, coal and/or other solid fuel feedstocks are gasified in an oxygen-blown, entrained-flow gasifier with continuous slag removal and a dry particulate removal system. The resulting product synthesis gas is used to fuel a combustion turbine generator whose exhaust is integrated with a heat recovery steam generator to drive a refurbished steam turbine generator. The gasifier uses technology initially developed by The Dow Chemical Company (the Destec Gasification Process), and now offered commercially by COP as the E-GAS ${ }^{\mathrm{TM}}$ technology. 
The demonstration project was completed in December 1999, having achieved all of its objectives. The facility built for this project is located at Cinergy Corporation's Wabash River Generating Station near West Terre Haute, Indiana.

The Wabash Repowering Project successfully demonstrated commercial application of the EGAS $^{\mathrm{TM}}$ coal gasification technology in conjunction with power generation. The combustion turbine generates $192 \mathrm{MW}$ while the repowered steam turbine generates $104 \mathrm{MW}$. With the system's parasitic load of $34 \mathrm{MW}$, net power production is $262 \mathrm{MW}$, which meets the target goal. By the end of the demonstration period of the Clean Coal Technology Program, operating time had exceeded 18,000 hours, with over 5 million MW of power produced. The WREL Plant operates successfully on baseload dispatch in the Cinergy power grid, and continues to operate as a privately owned facility after the demonstration period to supply synthesis gas to Cinergy.

Gasification is an environmentally superior means of utilizing domestic coal resources for power production. It also offers the opportunity to use lower quality, less expensive feedstocks such as petroleum coke. Petroleum coke operation was successfully tested at WREL as early as November 1997. Since August 2000, the facility has been operating on $100 \%$ petroleum coke feed. As of January 2003, over 800,000 tons of fuel grade petroleum coke has been processed, demonstrating the commercial viability of petroleum coke as the principle fuel for gasification.

Sulfur removal from the gasifier's solid feed is recovered and sold, as is the slag byproduct. Sulfur removal exceeds $97 \%$ resulting in sulfur oxides emissions of $0.1 \mathrm{lb} /$ million Btu, which is far below regulatory requirements of $1.2 \mathrm{lb} /$ million Btu. Particulate emissions are less than the detectible limit and nitrogen oxides emissions are $0.15 \mathrm{lb} /$ million Btu, which meets the current target for coal-fired power generation plants. The WREL facility is the cleanest solid fuel-based power plants in the world.

In a joint effort with DOE, a Cooperative Agreement for IMPPCCT was awarded under the Early Entrance Coproduction Plant (EECP). GEC, and now COP, and the industrial partners are investigating the use of synthesis gas produced by the E-GAS ${ }^{\mathrm{TM}}$ technology in a coproduction 
environment to enhance the efficiency and productivity of solid fuel gasification combined cycle plants.

The objective of this effort is to determine the feasibility of an EECP located at a specific site which produces some combination of electric power (or heat), fuels, and/or chemicals from synthesis gas derived from coal, or, coal in combination with some other carbonaceous feedstock. The project's intended result is to provide the necessary technical, financial, and environmental information that will be needed to move the EECP forward to detailed design, construction, and operation by industry.

During the reporting period, agreement was reached with DOE's patent counsel on the scope of the limited rights data to be provided under the Phase II of the Cooperative Agreement. Notice for approval of the Continuation Application of the project into Phase II to conduct RD\&T was received from DOE in September 2003. Funding available from Phase I will be used to fund the RD\&T activities in Phase II. The project schedule was adjusted to reflect the delay in starting Phase II, originally planned for April 2003. Potential technologies for removing sulfur contaminants from synthesis gas to the level required by methanol synthesis will be tested in slipstream units at the WREL facility during Phase II.

Preparation of a comprehensive Phase I Final Report, which will consolidate the remaining deliverables including the Initial Feasibility Report, Concept Report, Site Analysis Report, Economic Analysis, and Preliminary Project Financing Plan, continued during the reporting period. Progress was hindered by the change in ownership of GEC. The IMPPCCT Project, along with other DOE-funded projects previously managed by GEC, is being novated to COP, the new owner of the E-Gas ${ }^{\mathrm{TM}}$ gasification technology.

For the period of reporting, actual expenditure was $\$ 4,191$, with cumulative actual expenditure for the project to be $\$ 934,354$. The amounts include funding from DOE that is at $80 \%$ of the total, and cost share provided by the consortium members. Total budget for the project is $\$ 1,933,628$, with DOE providing $\$ 1,546,902$. The initial project tasks in Phase I had been mostly completed under budget. The scope of the remaining tasks was reduced, reflecting the 
results of the initial work. This has resulted in a significant amount of remaining funds in Phase I. The Continuation Application approved by DOE will allow the remaining funds to be used to conduct the RD\&T testing during Phase II. 


\subsection{ACTIVITIES}

The main activity conducted during this reporting period was finalizing the Continuation Application with DOE to transition the project from Phase I to Phase II to commence work under the RD\&T Plan. This and other activities were hindered by summer vacations taken by various personnel, and the transitioning of Global Energy personnel to COP from the sale of GEC and the E-Gas ${ }^{\mathrm{TM}}$ gasification technology.

\subsection{Finalizing the Continuation Application}

COP continued discussion with DOE's patent counsel on the scope of the limited rights data to be provided under the Phase II of the Cooperative Agreement in order to finalize the Continuation Application of the project to conduct RD\&T. Potential technologies for removing sulfur contaminants from synthesis gas to the level required by methanol synthesis will be tested in slipstream units at the WREL facility during Phase II.

\subsection{Planning for Phase II RD\&T}

COP continued discussions with partner companies for the RD\&T activities during Phase II of the project to make adjustment to the previous schedule in view of the delay in getting the Continuation Application approved. The main area being pursued in RD\&T is in synthesis gas contaminant removal. Both laboratory and slipstream testing at WREL were incorporated. Potential technologies to be evaluated include a regenerable activated carbon and a direct sulfur oxidation process to remove hydrogen sulfide and other sulfur species.

\subsection{Reporting and Deliverables}

During this reporting period, efforts continued on preparing the Phase I Final Report. Progress was hindered by the change in ownership of GEC. The IMPPCCT Project, along with other DOE-funded projects previously managed by GEC, is being novated to COP, the new owner of the E-Gas ${ }^{\mathrm{TM}}$ gasification technology. 


\subsection{RESULTS AND DISCUSSION}

\subsection{Finalizing the Continuation Application}

During the reporting period, agreement was reached with DOE's patent counsel on the scope of the limited rights data to be provided under the Phase II of the Cooperative Agreement. Notice for approval of the Continuation Application of the project into Phase II to conduct RD\&T was received from DOE in September 2003. Funding available from Phase I will be used to fund the RD\&T activities in Phase II. Cost sharing for Budget Period II will be at 35\% from industry and $65 \%$ from DOE. The project schedule was adjusted to reflect the delay in starting Phase II, originally planned for April 2003. Potential technologies for removing sulfur contaminants from synthesis gas to the level required by methanol synthesis will be tested in slipstream units at the WREL facility during Phase II.

\subsection{Planning for Phase II RD\&T}

COP continued discussions with partner companies for the RD\&T activities during Phase II of the project to make adjustment to the previous schedule in view of the delay in getting the Continuation Application approved. The main area being pursued in RD\&T is in synthesis gas contaminant removal. Both laboratory and slipstream testing at WREL were incorporated. Potential technologies to be evaluated include a regenerable activated carbon and a direct sulfur oxidation process to remove hydrogen sulfide and other sulfur species.

Small-scale slipstream testing at WREL, using actual synthesis gas being produced, is the preferred mode of testing. Laboratory testing will be conducted prior to the on-site slipstream testing to determine the optimum operating condition for the slipstream unit. The technology suppliers have agreed to provide the $35 \%$ cost-sharing required in Phase II.

COP updated the partner companies on the delay and status of getting the final modification to the Cooperative Agreement issued. Because of the delay in approving the transition to Phase II, the originally proposed schedule will need to be revised. The upcoming holiday season, as well as the harsh winter weather in the Terre Haute, Indiana area in January and February that makes outdoor activities undesirable, needs to be taken into consideration. A revised schedule will 
need to be established once the Continuation Application is approved and the slipstream testing projects are started.

\subsection{Reporting and Deliverables}

Preparation of a comprehensive Phase I Final Report, which will consolidate the remaining deliverables including the Initial Feasibility Report, Concept Report, Site Analysis Report, Economic Analysis, and Preliminary Project Financing Plan, continued during the reporting

period. Progress was hindered by the change in ownership of GEC and the transitioning of Global Energy personnel to COP. The IMPPCCT Project, along with other DOE-funded projects previously managed by GEC, is being novated to COP, the new owner of the E-Gas ${ }^{\mathrm{TM}}$ gasification technology. 


\subsection{CONCLUSIONS}

Under the guidance of the Project Management Plan, Phase I is led by GEC, now COP after its recent acquisition of the E-Gas ${ }^{\mathrm{TM}}$ technology, and is being performed by all team members including Air Products, Methanex, Dow Corning, Siemens Westinghouse, and Dow Chemical. The Phase I focus is on development of the economics, analysis of the commercialization potential for the gasification to methanol and power coproduction concept for future CEP, and preliminary engineering and environmental work for implementation of the methanol production addition at the WREL facility for the IMPPCCT demonstration. GEC/COP has utilized the analysis of potential IMPPCCT feedstocks to the gasification section, developed a preliminary site layout, determined synthesis gas quantities available to IMPPCCT, assessed final synthesis gas cleanup needs, provided the preliminary environmental assessment, reviewed modifications and tie-ins to the existing infrastructure at the WREL site, and worked jointly with Air Products and Methanex to develop the most advantageous economics for IMPPCCT based on either the liquid or gas-phase methanol processing units. Air Products has completed the review and application of the LPMEOH ${ }^{\mathrm{TM}}$ Process with methanol purification systems resulting in development of the methanol unit process package. An economic analysis for the Wabash IMPPCCT and for the CEP has also been completed. Concerns on process compatibility were identified during the course of the evaluation, and potential process blocks that could alleviate the concerns were proposed in the RD\&T Plan for further investigation. Current activities are focused on transitioning the project from Phase I to Phase II to commence on the RD\&T activities.

\subsection{Finalizing the Continuation Application}

During the reporting period, agreement was reached with DOE's patent counsel on the scope of the limited rights data to be provided under the Phase II of the Cooperative Agreement. Notice for approval of the Continuation Application of the project into Phase II to conduct RD\&T was received from DOE in September 2003. Funding available from Phase I will be used to fund the RD\&T activities in Phase II. Potential technologies for removing sulfur contaminants from synthesis gas to the level required by methanol synthesis will be tested in slipstream units at the WREL facility during Phase II. 


\subsection{Planning for Phase II RD\&T}

COP updated the partner companies on the delay and status of getting the final modification to the Cooperative Agreement issued. Because of the delayed in approving the transition to Phase II, the originally proposed schedule will need to be revised. The upcoming holiday season, as well as the harsh winter weather in the Terre Haute, Indiana area in January and February that makes outdoor activities undesirable, needs to be taken into consideration. A revised schedule will be established once the slipstream testing projects are initiated.

\subsection{Reporting and Deliverables}

Preparation of a comprehensive Phase I Final Report, which will consolidate the remaining deliverables including the Initial Feasibility Report, Concept Report, Site Analysis Report, Economic Analysis, and Preliminary Project Financing Plan, continued during the reporting period. Progress was hindered by the change in ownership of GEC and the transitioning of Global Energy personnel to COP. The IMPPCCT Project, along with other DOE-funded projects previously managed by GEC, is being novated to COP, the new owner of the E-Gas ${ }^{\mathrm{TM}}$ gasification technology. 


\subsection{MILESTONES \& PLANS}

\subsection{Plans for Commencing on Phase II and Completing Phase I}

Partner companies in the Phase II RD\&T, including Gas Technology Institute, TDA Research, Inc., and Nucon International, Inc., are being notified of DOE's formal approval of the Continuation Application and the transition to Phase II. Kickoff meetings will be held to discuss the implementation plan, schedule, and project management items. A Project Management Plan will be prepared and submitted to DOE for approval.

Efforts will continue simultaneously to complete the consolidated Phase I Final Report.

\subsection{Project Schedule and Milestones}

Figure 7.2.1 illustrates a revised Phase I project milestone map. The blocks shown in full shading are those associated with the critical path to completion of Phase I. Hollow blocks are tasks that support the overall timetable and/or result in deliverable items to the DOE. Progress on the project was hindered for most of 2002 due to loss and turnover of critical personnel. This schedule was granted several extensions by DOE.

Because of the delayed in approving the transition to Phase II, the originally proposed Phase II schedule will need to be revised. The upcoming holiday season, as well as the harsh winter weather in the Terre Haute, Indiana area in January and February that makes outdoor activities undesirable, needs to be taken into consideration. A revised schedule will be established once the slipstream testing projects are initiated.

\subsection{Project Spending -- Plan and Actuals}

As shown in Figure 7.3.1, actual expenditure for the reporting period was $\$ 14,716$, which includes an adjustment of $\$ 2,500$ for an invoice from Dow Corning received by Global Energy in the previous reporting period that was not billed correctly to DOE. The cumulative actual expenditure for the project was $\$ 944,878$. The figures include funding from DOE that is at $80 \%$ of the total, and cost share provided by the consortium members. Total budget for the project is $\$ 1,933,628$, with DOE providing $\$ 1,546,902$. 
Figure 7.3.2 presents the DOE cost share for the Phase I effort. Total DOE contribution to-date is $\$ 755,902$. Spending is far below original plan. The initial project tasks in Phase I had been mostly completed under budget. The scope of the remaining tasks was reduced, reflecting the results of the initial work (e.g. little work is needed on a Preliminary Finance Plan for a project that is not slated to go forward in the near future). This has resulted in a significant amount of remaining funds $(\$ 791,000)$ in Phase I. DOE has approved the Continuation Application to carry over the unspent funding into Phase II to conduct RD\&T activities. Cost sharing for Budget Period II will be at 35\% from industry and $65 \%$ from DOE. 
Figure 7.2.1 : Phase I, IMPPCCT Milestones (rev.)

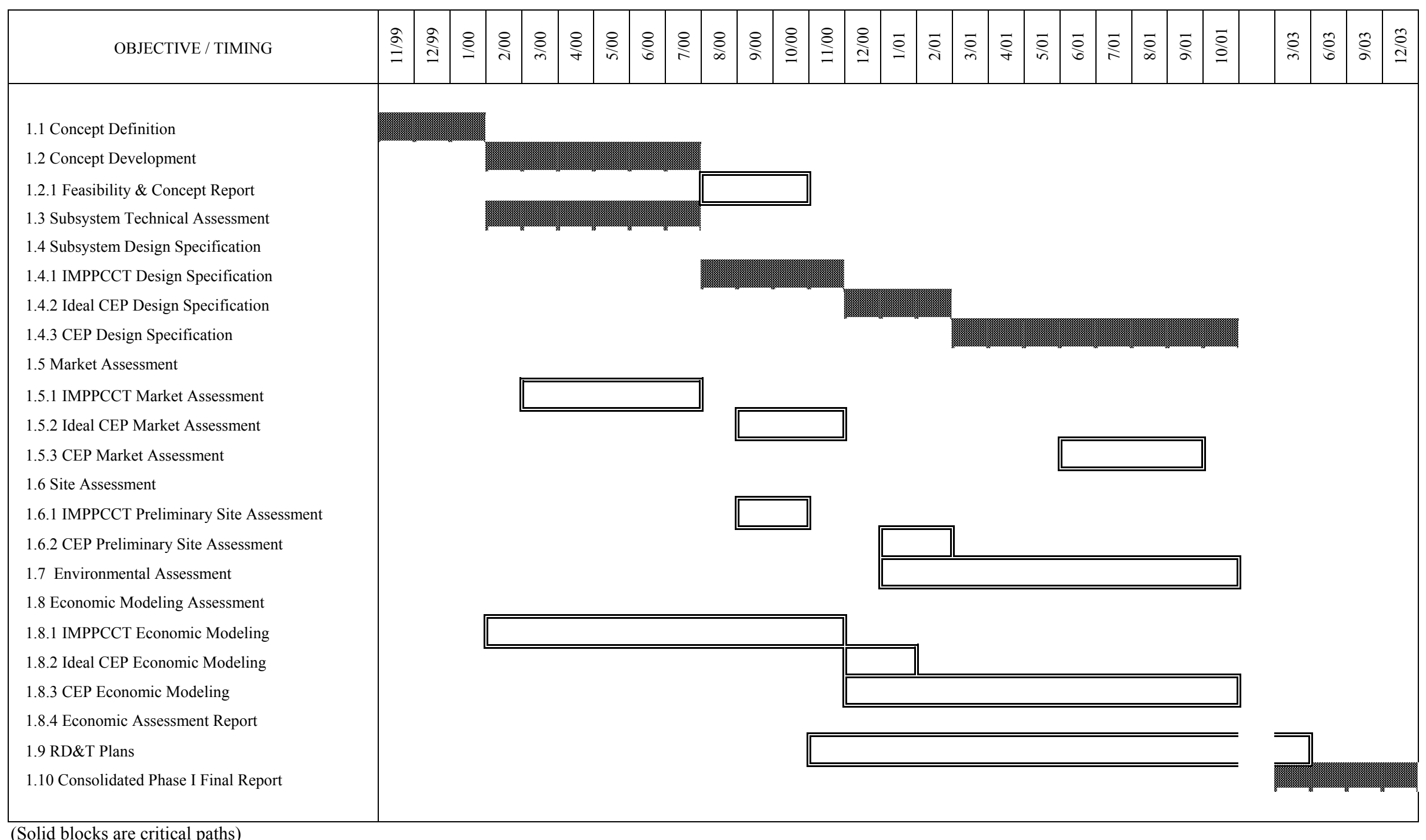


Figure 7.3.1: Phase I Project Spending -- Overall

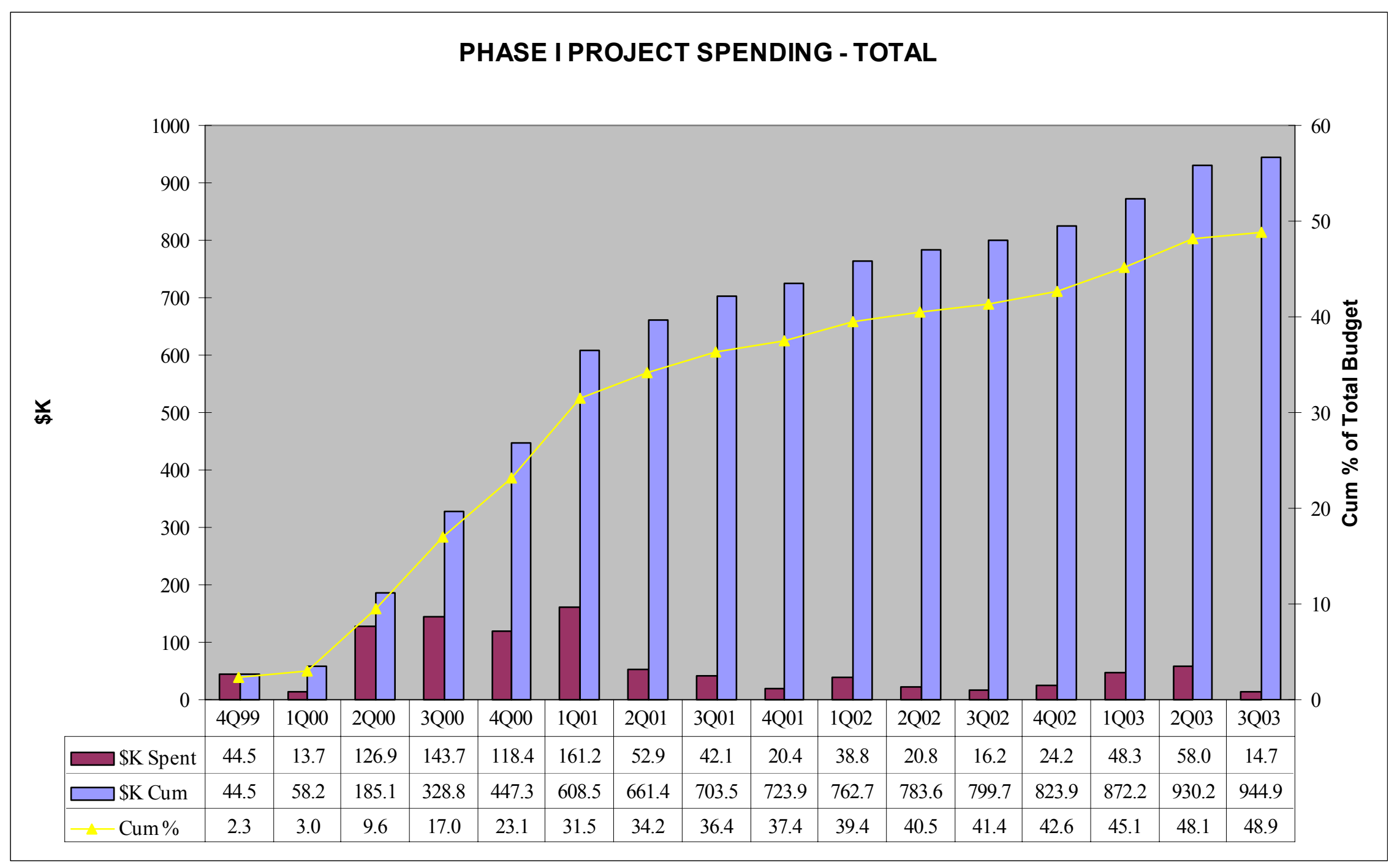


Figure 7.3.2: Phase I Project Spending -- DOE Funding

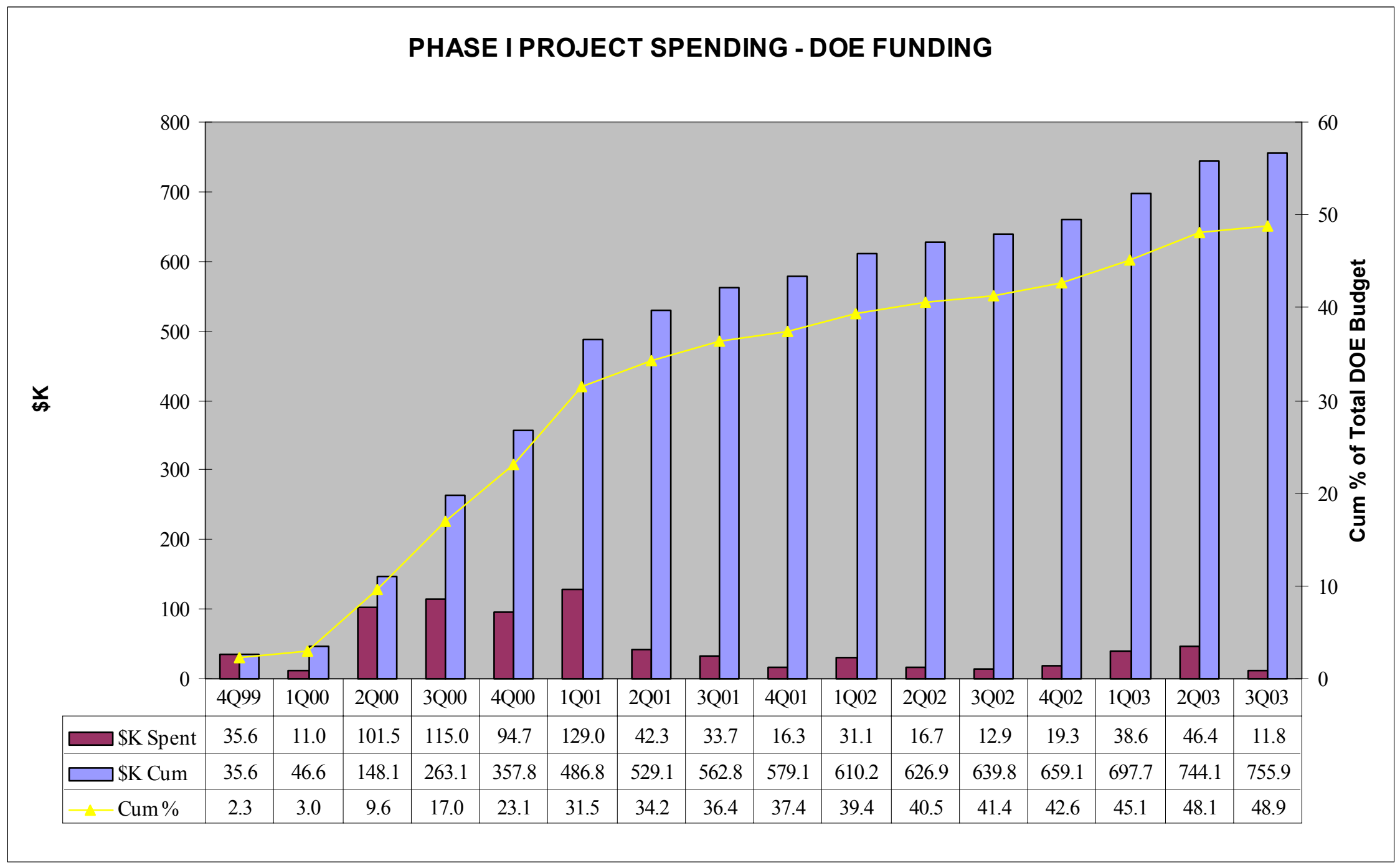




\subsection{REFERENCES}

\subsection{Selected References Available via the Internet}

1. "National Energy Policy", issued by the White House in May 2001. The Wabash River facility and Global Energy received mention in a dedicated sidebar on page 3-6. http://www.whitehouse.gov/energy/Chapter3.pdf

2. "Wabash River Coal Gasification Repowering Project, An Update", Department of Energy Topical Report No. 20, September 2000, summarizes the history of the Wabash River facility and its construction and four year demonstration under the DOE's Clean Coal Technology program. http://www.lanl.gov/projects/cctc/topicalreports/documents/topical20.pdf

3. "Wabash River Coal Gasification Repowering Project Final Technical Report”, August 2000, 358 pages. This is a very detailed look at the Wabash River facility and its operation 1995-1999. http://www.lanl.gov/projects/cctc/resources/pdfs/wabsh/Final\%20_Report.pdf

4. "Gasification Plant Performance and Cost Optimization", May 2002, (23 MB). The final report of Task 1 of this comprehensive (\$2.4 million) study performed by Global Energy, Nexant and Bechtel under subcontract to the DOE to identify cost savings in the next generation of integrated gasification and coproduction facilities utilizing the E-Gas Technology. Detailed cost estimating by Bechtel. http://www.netl.doe.gov/coalpower/gasification/projects/systems/docs/40342R01.PDF

5. "Wabash River Coal Gasification Repowering Project, A DOE Assessment", January 2002. This is the DOE's official post-project assessment of the Wabash River project. http://www.lanl.gov/projects/cctc/resources/pdfs/wabsh/netl1164.pdf

6. "Environmental Benefits of Clean Coal Technologies" Department of Energy Topical Report No. 18, April 2001. This report describes a variety of processes that are capable of meeting existing and emerging environmental regulations and competing economically in a deregulated electric power marketplace http://www.lanl.gov/projects/cctc/topicalreports/documents/topical18.pdf

7. "Coproduction of Power, Fuel, and Chemicals" Department of Energy Topical Report No. 21, September 2001. A description of the production of synthesis gas (syngas) from coal, the production of electricity from combusting a portion of the syngas and conversion of the remaining syngas to high-value fuels and chemicals. http://www.lanl.gov/projects/cctc/topicalreports/documents/topical21.pdf

8. The Gasification Technology Council maintains a website (www.gasification.org) that includes a library of the papers presented at recent conferences. Papers presented by Global Energy in 2002 \& 2001:

"Wabash River Repowering IGCC Operations and Performance Update Report", October 2002 http://www.gasification.org/Presentations/2002 papers/GTC02010.pdf

"Comparative IGCC Cost \& performance for Domestic Coals", October 2002 http://www.gasification.org/Presentations/2002_papers/GTC02018.pdf

"NOx Control in IGCC Combustion Turbines: Steam vs. Nitrogen", October 2002 http://www.gasification.org/Presentations/2002_papers/GTC02022.pdf

“Optimized Petroleum Coke IGCC Coproduction Plant", October 2001 http://www.gasification.org/98GTC/GTC01018.pdf

"Environmental Performance of IGCC Repowering for Conventional Coal Power Plants", October 2001 http://www.gasification.org/98GTC/GTC01037.pdf 